\title{
Biological efficiency and nutritional composition of Pleurotus djamor cultivated on bagasse of Agave salmiana
}

\author{
Brianda Susana Velázquez de Lucio \\ Universidad Politecnica de Pachuca \\ Edna María Hernández Domínguez \\ Universidad Politecnica de Pachuca \\ Xochitl Tovar Jiménez \\ Universidad Politecnica de Pachuca \\ Laura Sofia Castillo Ortega \\ Universidad Politécnica de Pachuca: Universidad Politecnica de Pachuca \\ Gerardo Díaz Godínez \\ Universidad Autónoma de Tlaxcala: Universidad Autonoma de Tlaxcala \\ Alejandro Tellez Jurado \\ Universidad Politécnica de Pachuca: Universidad Politecnica de Pachuca \\ Jorge Alvarez Cervantes ( $\square$ jorge_ac85@upp.edu.mx ) \\ Universidad Politecnica de Pachuca https://orcid.org/0000-0002-0379-5588
}

\section{Research Article}

Keywords: Agave salmiana, biological efficiency, bagasse, fruiting bodies, Pleurotus djamor

Posted Date: June 22nd, 2021

DOI: https://doi.org/10.21203/rs.3.rs-629407/v1

License: (1) This work is licensed under a Creative Commons Attribution 4.0 International License. Read Full License 


\begin{abstract}
The objective of the present study was to use molecular techniques to identify a wild mushroom isolated from A. salmiana, and then evaluate its biological efficiency, production rate, and nutritional and morphological characteristics when grown on $A$. salmiana bagasse with various concentrations of urea as a source of nitrogen. Two types of inoculum were employed: in grain (WG) and pellet (WP) form. The substrate was supplemented with total nitrogen concentrations (TN) of $0.77,0.95,1.14,1.32$, and $1.5 \%$ to evaluate its effect on the biological efficiency (BE), production rate $(\mathrm{PR})$, and morphological and nutritional characteristics of the fruiting bodies. The molecular analysis of the ITS region permitted the amplification of a product of $750 \mathrm{pb}$. The mushroom was identified as Pleurotus djamor. After supplementing the substrate with urea, a BE of $70 \%$ was obtained in the sample inoculated with WG at $1.32 \%$ TN. Observations found that the TN concentration of $1.5 \%$ produced malformations in the fruiting bodies. The analysis of the sporocarps indicated a raw protein content (RP) of $15-26 \%$ and that the mushroom's nutritional composition changed according to the inoculum utilized and the percentage of nitrogen in the substrate. This is the first report on the isolation of $P$. djamor on $A$. salmiana as an atypical substrate, and so represents an opportunity for further study and commercialization. To its chemical composition and high availability, $A$. salmiana bagasse is a suitable alternative substrate for cultivating edible mushrooms, specifically P. djamor.
\end{abstract}

\title{
Introduction
}

Cultivation of edible mushrooms has increased worldwide in recent years due to their culinary characteristics, health benefits, biological activity (antioxidant, antihypertensive, anticancerogenic), and multiple biotechnological and environmental applications, among other reasons. The genus Pleurotus is the second-most widely cultivated mushroom on the planet with an estimated production of $6.46 \times 10^{9} \mathrm{~kg}$ (Arango and Nieto 2013; Sardar et al. 2017; Royse et al. 2017). Some 50 species of this genus have been reported. Its cultivation requirements and nutraceutical and biodegradative properties have attracted interest, and it is now a promising agroindustrial product with expanding cultivation in Latin America and other areas of the world (Royse and Sánchez 2001; Barba et al. 2016; Salmones 2017).

In Mexico, the species with the highest production volumes are Pleurotus ostreatus, P. djamor, and P. pulmonaris (Salmones 2017). They are cultivated on a broad range of agroforest by-products: rice chaff, oats, wheat, cotton, palm oil, scrub, sawdust, pulps, fruit peels, jute waste, bagasse, and other kinds of chaff, among others (Bellettini et al. 2019), all of which are rich in the carbon, nitrogen, sulfur, and phosphorus necessary for the development of mushroom biomass (Gregori et al. 2007). Agave bagasse has these same properties, and estimates indicate that this material is produced at a rate of 4'709,000 tons per day. Accumulation of this bagasse causes environmental problems and contributes to the proliferation of rodents, insects, bacteria, and fungi (Gallardo 2018). It has been proposed as an alternative substrate for growing mushrooms (Heredia-Solís et al. 2014; Heredia-Solís et al. 2017), but more studies are required to improve cultivation and production conditions.

Due to the genus Pleurotus' ability to grow in diverse substrates, it has been found on agave plants where it develops mainly on shoots near the ground around the base of plant, and in the cavity of exhausted magueys. It has been identified as $P$. opuntiae. This genus, however, is subject to controversy because not all the mushrooms that grow on these plants correspond to this species. In these circumstances, molecular studies are highly useful (Granados 1993; Barrales and Mata 2016; Heredía-Solís et al. 2017; Zervakis et al. 2019).

The objective of the present study was to use molecular techniques to identify a wild mushroom isolated from A. salmiana, and then evaluate its biological efficiency, production rate, and nutritional and morphological characteristics when grown on $A$. salmiana bagasse with various concentrations of urea as a source of nitrogen.

\section{Materials And Methods Isolation and cultivation}

The wild mushroom was isolated from a fruiting body that developed on A. salmiana in the municipality of Chilcuautla, Hidalgo, Mexico $\left(20^{\circ} 20^{\prime} 00^{\prime \prime} \mathrm{N} 99^{\circ} 14^{\prime} 00^{\prime \prime} \mathrm{Or}\right)$. The hymenia were cut in $1-\mathrm{cm}^{2}$ fragments, subjected to treatment (5 min in sterile distilled water, 5 min in a hypochlorite solution at $5 \%$, and washing with sterile water), and then seeded on plates in potato dextrose agar (PDA) medium for 7 days at $28^{\circ} \mathrm{C}$ until the mycelium characteristic of the mushroom was obtained. Re-seedings were done periodically to achieve purification.

\section{Molecular identification}

\section{DNA extraction}

The mushroom's genomic DNA was obtained from 0.750-g pellets recovered by filtration, frozen, and then lyophilized from a liquid culture in Kirk medium for 7 days, utilizing the protocol proposed and modified by Huanca-Mamani et al. (2014). The concentration and purity of the 
DNA were measured in a NANODROP 2000, and integrity was verified by electrophoresis in agarose gel at $1 \%$ (30 min, $80 \mathrm{~V}$, electrophoresis chamber).

\section{Amplification and sequencing}

The ITS1-5.8-ITS2 region of the DNA of the mushroom was amplified by the polymerase chain reaction (PCR) using the universal oligonucleotides ITS1 and ITS4, following Díaz et al. (2014) modified protocol. The product of PCR was analyzed by electrophoresis in agarose gel at $1 \%$. The base pairs were determined by comparison to the $1 \mathrm{~Kb}$ marker. The Wizard® S.V. Gel and PCR Clean Up System kit was utilized to purify the PCR products. Sequencing was performed at the Unidad de Síntesis y Secuenciación de ADN at the Instituto de Biotecnología of the National Autonomous University of Mexico (UNAM).

\section{Analysis of the sequence}

The sequence was compared to the NCBI's DNA database (www.ncbi.nlm.nih.gov) using the Basic Local Alignment Search Tool (BLAST) (Altschul et al. 1990). A total of nine sequences of Pleurotus were recovered, along with one sequence of Fusarium phyllophilum, to create the phylogenetic tree (Table 1). The evolution model employed was GTR I+ G, determined by ModelTest v. 2.3 (Nylander, 2004). The tree was generated on the Phylogeny.fr platform (https://www.phylogeny.fr/; Dereeper et al. 2008) using the ClustalW, Gblocks, Mr.Bayes, and TreeDyn programs (Thompson et al. 1994; Huelsenbeck and Ronquist 2001; Chevenet et al. 2006; Dereeper et al. 2008; Dereeper et al. 2010). The phylogenetic tree was visualized in FigTree v1.4.4. (Rambaut 2018). The sequence was deposited in GenBank under access number MW581271. The phylogenetic tree was deposited in TreeBASE (Accession URL:http://purl.org/phylo/treebase/phylows/study/TB2:S28312).

Table 1

Reference ITS sequences of Pleurotus and Furarium phyllophilum (external organism) for the Phylogenetic analysis obtained from GenBank.

\begin{tabular}{|c|c|c|c|}
\hline Species & Geographic Origin & $\begin{array}{l}\text { Assession No. } \\
\text { GenBank }\end{array}$ & Reference \\
\hline Pleurotus opuntiae & India & MN477934 & $\begin{array}{l}\text { Kantharaja and Krishnappa, not } \\
\text { published }\end{array}$ \\
\hline Pleurotus djamor & India & MF574728 & Suresh and Kalaiselvam, not published. \\
\hline Pleurotus djamor & Cuba & JN637828 & Manzano et al. not published \\
\hline Pleurotus djamor & India & MG328900 & $\begin{array}{l}\text { Johney, Radhai Sri, and Ragunathan, } \\
2018\end{array}$ \\
\hline Pleurotus djamor & India & MN398667 & Pandey et al. not published \\
\hline Pleurotus djamor & Cuernavaca, Morelos, México & GU722273 & Huerta et al. 2010 \\
\hline Pleurotus djamor & Mérida, Yucatán, México & GU722271 & Huerta et al. 2010 \\
\hline Pleurotus djamor & $\begin{array}{l}\text { Talquian, Union Juarez, Chiapas, } \\
\text { México }\end{array}$ & GU722265 & Huerta et al. 2010 \\
\hline $\begin{array}{l}\text { Pleurotus } \\
\text { ostreatoroseus }\end{array}$ & South Korea & MG282434 & Yan, not published \\
\hline Pleurotus opuntiae & Tetela de Ocampo, Puebla, México & MK757594 & Portilla-Segura et al. 2019 \\
\hline Pleurotus opuntiae & India & KY214255 & Krishnapriya et al. 2017 \\
\hline Fusarium phyllophilum & - & KR909430 & Al-Hatmi et al. 2016 \\
\hline
\end{tabular}

Cultivation and production parameters of Pleurotus spp.

\section{Preparation of the primary inoculum}

The primary inoculum was obtained in two forms: wheat grains (WG) and pellets (WP). The former was prepared with wheat seeds hydrated for $12 \mathrm{~h}$. Excess water was drained and $250 \mathrm{~g}$ of the wheat were placed in polypaper bags. These were sterilized for $15 \mathrm{~min}$ and then inoculated with $15,1-\mathrm{cm}^{2}$ squares of the mushroom's mycelium. Incubation was performed at $28^{\circ} \mathrm{C}$ under total darkness until the mycelium completely invaded the seeds. The WP were prepared in 250-mL Erlenmeyer flasks containing $100 \mathrm{~mL}$ of potato dextrose broth. They were sterilized and inoculated with $10 \mathrm{~mL}$ of the mushroom's mycelium suspended in sterile water, and incubated at $28^{\circ} \mathrm{C}$ under stirring at $160 \mathrm{rpm}$ until uniform pellets formed.

\section{Selection and characterization of the substrate}


The A. salmiana bagasse employed consisted of residues from the pulque, inulin, and honey industries. It was provided by the Coorporativo Magueyero San Isidro, S.A. de C.V. in the municipality of Nanacamilpa, Tlaxcala, Mexico $\left(19^{\circ} 29^{\prime} 00^{\prime \prime} \mathrm{N} 98^{\circ} 32^{\prime} 00^{\prime \prime} 0\right)$. Selecting the residue required physicochemical analysis of the bagasse from the shoots, the pineapple, and a 50:50 mixture of shoots:pineapple. The following determinations were made: moisture (M) by the AOAC 930.15 method, ash (C) by the AOAC 942.05 method, organic material (OM) by difference of ash, crude protein (CP) by the adapted A.O.A.C. 955.04 method, total organic carbon (TOC) by calculation (OM/1.74) (Gouleke 1977), and the $\mathrm{C} / \mathrm{N}$ ratio. $\mathrm{pH}$ was measured in extracts of distilled water in a weight/volume ratio of 1:5 (Crespo et al. 2018 ).

\section{Inoculation of the substrate}

Bagasse from the shoots of $A$. salmiana was washed in distilled water and pasteurized at $65^{\circ} \mathrm{C}$ for 60 min. Excess water was drained and the material was left to cool at ambient temperature. Once cooled, 27 bags, each containing $150 \mathrm{~g}$ (dry weight) of $A$. salmiana bagasse, were inoculated for each experiment (WG, WP) and distributed in 5 treatments for later supplementation with urea. The procedure followed the methodology proposed by López-Rodríguez et al. (2008) for inoculation with WG, while for inoculation with WP, we took the total content of the pellets from each flask, filtered the culture broth and deposited the pellets in the center of the polypaper bags that contained the previously sterilized substrate, according to Abdullah et al.'s modified protocol (2013).

\section{Supplementation with urea}

During supplementation of the substrate, the total nitrogen content (TN) of the bagasse of the $A$. salmiana shoots was taken as the initial parameter. The experimental design for WG and WP consisted in 9 treatments (T1: 0.77\% TN, T2: 0.95\% TN, T3: 1.14\% TN, T4: 1.32\% TN, T5: $1.5 \% \mathrm{TN}$ ) and 3 repeats in which the minimum, maximum, and central values for total $\mathrm{N}$ in the $A$. salmiana bagasse were $0.95,1.5$, and $1.32 \%$ TN, respectively. Nitrogen was calculated in percentage amounts equivalent to the weight in grams of the urea. The solutions were prepared with distilled water and sterilized with a $0.2-\mu \mathrm{m}$ cellulose membrane. A potentiometer was used to measure $\mathrm{pH}$.

Supplementation was performed 3 days after inoculation using a sterile syringe to cover all the bags. The amount of solution administered was calculated on the basis of the moisture of the inoculated bags, adjusted to $80 \%$. Once all the bags were supplemented, they were kept under darkness until primordia appeared, protocol modified by Monterroso (2009).

\section{Fructification and harvesting}

After the appearance of the primordia, the bagasse was exposed to light at a temperature of $18-20^{\circ} \mathrm{C}$ and a relative humidity of $80-90 \%$ until mature fruiting bodies were obtained (López-Rodríguez et al. 2008). The mushrooms were gathered manually with a sterile scalpel and measured. This procedure was repeated for each harvest (Fernández 2004).

\section{Evaluation of productive parameters}

The following parameters were recorded: running time of the mycelium on the substrate, precociousness (time of appearance of primordia), and fructification. The productive parameters determined were biological efficiency (BE) and production rate (PR) (Bernabé-González et al. 2004):

$$
\text { Biological ef ficiency }(B E)=\frac{\text { Weight of the fresh mushrooms }(\mathrm{g})}{\text { Weight of the dry substrate }(\mathrm{g})} * 100 \quad \text { Eq. } 1
$$

Production rate $(P R)=\frac{\text { Biological efficiency }}{\text { Days from seeding to the end of production }} \quad$ Eq. 2

\section{Morphological and proximal chemical characterization of the fruiting bodies}

The fruiting bodies from each treatment were characterized morphologically by texture, growth, color, form of the laminae, and pileus. For the proximal chemical composition, moisture (M) was determined by method 930.15 , crude protein (CP) by the adapted 955.04 method, ethereal extract (EE) by method 920.39, and ash (C) by method 942.05, following the methodologies established by the AOAC (Association of Official Analytical Chemists).

\section{Statistical analyses}

Data analyses were performed using the Minitab 19 statistical program. A one-way ANOVA was applied with a Tukey test for multiple comparisons. The confidence level was $95 \%$.

\section{Results}




\section{Molecular identification}

The molecular study of the fungus isolated from $A$. salmiana allowed us to obtain one amplification product with a size of 750 pb. It was identified as Pleurotus djamor. The sequence was deposited in GenBank under access number MW581271, and a phylogenetic tree was elaborated (Fig. 1 Accession URL:http://purl.org/phylo/treebase/phylows/study/TB2:S28312) using the sequences of Pleurotus available at GenBank.

\section{Culture and productive parameters of P. djamor}

Table 2 shows the results of the characterization of various sections of the bagasse of $A$. salmiana. The residue of the pineapples is rich in crude protein (CP) at $11.51 \%$, compared to just $4.8 \%$ in bagasse from the shoots.

Table 2

Chemical composition of Agave salmiana bagasse.

\begin{tabular}{|llll|}
\hline & Shoots & Pineapples & Pineapples- shoots (50:50) \\
\hline Moisture (\%) & $10.61 \pm 0.4$ & $10.14 \pm 0.3$ & $11.92 \pm 0.3$ \\
\hline Ash (\%) & $10.51 \pm 0.4$ & $10.91 \pm 0.8$ & $11.33 \pm 0.3$ \\
\hline Organic matter (\%) & $89.57 \pm 0.4$ & $89.09 \pm 0.8$ & $88.67 \pm 0.3$ \\
\hline Crude protein (\%) & $4.80 \pm 0$ & $11.51 \pm 0.5$ & $8.75 \pm 0.8$ \\
\hline Nitrogen (\%) & $0.77 \pm 0$ & $1.84 \pm 0.1$ & $1.40 \pm 0.1$ \\
\hline TOC (\%) & $49.76 \pm 0.2$ & $49.49 \pm 0.4$ & $49.26 \pm 0.2$ \\
\hline C/N ratio & 64.62 & 26.90 & 35.19 \\
\hline pH & $5.14 \pm 0.6$ & $5.90 \pm 0.2$ & $5.77 \pm 0.03$ \\
\hline \pm Standard deviation & & & \\
\hline TOC: Total organic carbón & & & \\
\hline
\end{tabular}

During cultivation, we analyzed two types of primary inoculum: a traditional one that utilizes wheat grains as support, and a second made from pellets of the mushroom itself. Observations showed that the type of primary inoculum used did not affect the development of $P$. djamor, and that the use of the inoculum had no impact on the mycelial growth of the mushroom on the substrate. The inoculum in pellet form (WP) colonized the $A$. salmiana bagasse in 13 days, while the inoculum in grain form (WG) required 25 days. The seeds that resulted from the WG treatment were homogeneous, especially in the wheat grain, while the WP pellets varied in size, were semi-uniform, and beige in color. Neither product showed signs of contamination.

Table 3 shows the time of appearance of the primordia (precociousness), and the first and second harvests of the experiments inoculated with WG and WP. Table 4 displays the different concentrations of urea and BE and PR. Because the bags inoculated with WG increased the concentration of nitrogen, precociousness decreased. In treatment T1 (substrate not supplemented with nitrogen), 14 days were required for the first primordia to appear, while in T2 and T3 the time of appearance was 11 days, and for treatment T5 it was 10 . In contrast, in the bags with WP precociousness increased with higher concentrations of nitrogen, reaching 14 days in T1 and T2, and 18 days in T3, T4, and T5.

Table 3

Precociousness and harvests of $P$. djamor on $A$. salmiana bagasse after the WG and WP treatments.

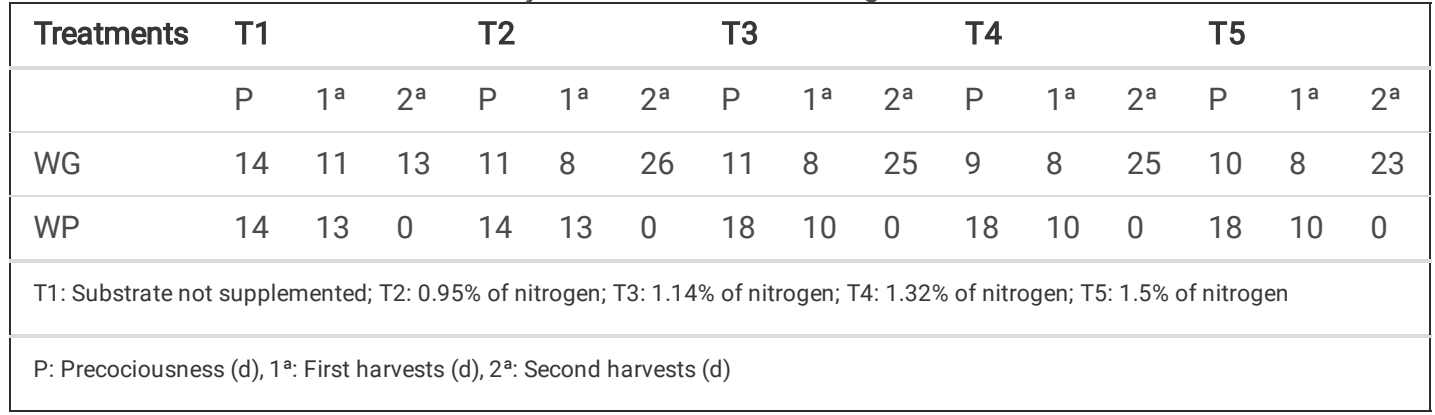


Table 4

Production parameters of P. djamor on A. salmiana bagasse using wheat seeds.

\begin{tabular}{|c|c|c|c|c|c|c|c|c|c|c|}
\hline Type of & $\mathrm{T} 1$ & & $\mathrm{~T} 2$ & & T3 & & T4 & & T5 & \\
\hline & $\mathrm{BE}$ & PR & $\mathrm{BE}$ & PR & BE & PR & $\mathrm{BE}$ & PR & $\mathrm{BE}$ & PR \\
\hline WG & $\begin{array}{l}58.33 \pm \\
9^{a}\end{array}$ & $\begin{array}{l}0.97 \pm \\
0.2^{\mathrm{a}}\end{array}$ & $\begin{array}{l}61.11 \pm \\
10^{a}\end{array}$ & $\begin{array}{l}1.02 \pm \\
0.2^{\mathrm{a}}\end{array}$ & $\begin{array}{l}63.41 \pm \\
8^{a}\end{array}$ & $\begin{array}{l}1.06 \pm \\
0.1^{\mathrm{a}}\end{array}$ & $\begin{array}{l}70.00 \pm \\
9^{a}\end{array}$ & $\begin{array}{l}1.17 \pm \\
0.1^{\mathrm{a}}\end{array}$ & $\begin{array}{l}70.56 \pm \\
10^{a}\end{array}$ & $\begin{array}{l}1.18 \pm \\
0.2^{\mathrm{a}}\end{array}$ \\
\hline WP & $\begin{array}{l}20.56 \pm \\
4^{a}\end{array}$ & $\begin{array}{l}0.34 \pm \\
0.1^{a}\end{array}$ & $\begin{array}{l}23.33 \pm \\
3^{a}\end{array}$ & $\begin{array}{l}0.39 \pm \\
0.1^{a}\end{array}$ & $\begin{array}{l}44.07 \pm \\
7^{b}\end{array}$ & $\begin{array}{l}0.73 \pm \\
0.1^{\mathrm{b}}\end{array}$ & $\begin{array}{l}42.22 \pm \\
5^{b}\end{array}$ & $\begin{array}{l}0.70 \pm \\
0.1^{\mathrm{b}}\end{array}$ & $\begin{array}{l}38.11 \pm \\
5^{b}\end{array}$ & $\begin{array}{l}0.64 \pm \\
0.1^{b}\end{array}$ \\
\hline
\end{tabular}

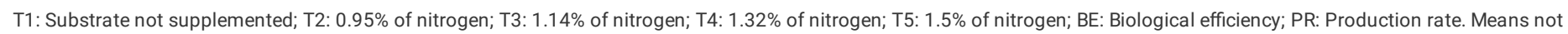

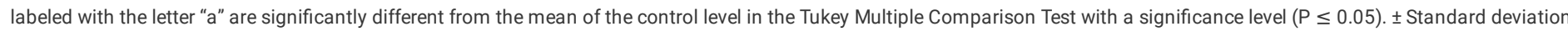

Two harvests were obtained from the bags inoculated with WG. The first (T1) at 25 days from inoculation. For treatments T2 to T5, the first harvest was obtained after an average of $17 \pm 1$ days. Regarding the second harvest, for T1 it was obtained after 38 days, while for T2 to T5 the time required was 41-45 days. The treatments inoculated with WP only produced one wave of mushrooms at $27 \pm 1$ days after inoculation. This represents an economic disadvantage for production. It is likely that the WG treatments included nutrients that promoted the growth of the mushroom, while the WP inoculum lacked these compounds that strongly impact the number of harvests achieved. The BE and PR of the treatments inoculated with WG increased with respect to the non-supplemented treatment (T1) and as the concentration of TN in the bagasse increased. The maximum BE achieved was 70\%, while the maximum PR was 1.18, both in T5. The BE and PR of the treatments inoculated with WP were lower, with T3 showing the highest values for these two parameters (44\% and 0.73). The evidence from this experiment allowed us to determine that the primary inoculum based on pellets (WP) did not generate higher yields in the cultivation of $P$. djamor, as was expected. In contrast, the BE and PR of the bags inoculated with WG and supplemented with urea as a source of nitrogen improved.

The fruiting bodies of the WG and WP experiments are shown in Fig. 2. In both cases, they were of beige color with regular growth, a cottony texture, and smooth decurrent laminae. However, the form of the pileus of the mushrooms inoculated with WG was flabelliform, while that of the mushrooms inoculated with WP was infundibuliform. In the WG treatments, $31 \%$ of the fruiting bodies from T1 reached a size of $5-8 \mathrm{~cm}$, $39 \%$ measured $8-13 \mathrm{~cm}$, but only $4 \%$ achieved a size of $13-16 \mathrm{~cm}$. In T2 with WG, $54 \%$ of the mushrooms measured $8-13 \mathrm{~cm}$. For T3 the figures were 62 for $8-13 \mathrm{~cm}$ and $24 \%$ between 5 and $8 \mathrm{~cm}$. For T4, 39\% of the carpophores reached a size of $8-13 \mathrm{~cm}$. For T5, 48\% of the fruiting bodies measured $8-13 \mathrm{~cm}$. Although some mushrooms from T4 and T5 achieved average size, some carpophores showed malformations in the clusters and caps. In addition, almost $20 \%$ of the fruiting bodies in T4 detained their development after day 14 (Fig. 3 ).

Regarding the WP experiment, $45.5 \%$ of the fruiting bodies in T1 measured $5-8 \mathrm{~cm}$, but only $6 \%$ reached $10-13 \mathrm{~cm}$. In T2, 35\% of the carpophores were classified in a size of $5-8 \mathrm{~cm}$. In contrast, observations of T3 showed that $16 \%$ of the mushrooms achieved a size $\geq 16 \mathrm{~cm}$ with a predominance of carpophores between 10 and $13 \mathrm{~cm}$. The average size in T4 was 10-13 cm (37\%), while in T5, 21\% of the carpophores detained their growth.

\section{Nutritional composition of the fruiting bodies}

The effect of the type of inoculum and the substrate supplemented with urea on the morphology and nutritional composition of the fruiting bodies are shown in Tables 5 and 6, respectively. 
Table 5

Morphological characterization of the fruiting bodies during the WG and WP experiments.

\begin{tabular}{|c|c|c|c|c|c|c|c|c|c|c|}
\hline & WG & & & & & WP & & & & \\
\hline & Texture & Growth & Color & Laminae & Pileus & Textura & Growth & Color & Laminae & Pileus \\
\hline $\mathrm{T} 1$ & Cottony & Regular & White & Decurrent & Flabelliform & Cottony & Regular & Cream & Decurrent & Infundibuliform \\
\hline T2 & Cottony & Regular & Cream & Decurrent & Flabelliform & Cottony & Regular & Cream & Decurrent & Infundibuliform \\
\hline T3 & Cottony & Regular & Cream & Decurrent & Flabelliform & Cottony & Regular & Cream & Decurrent & Infundibuliform \\
\hline $\mathrm{T} 4$ & Cottony & Exuberant & Cream & Decurrent & $\begin{array}{l}\text { Flabelliform/ } \\
\text { Malformations }\end{array}$ & Cottony & Regular & Cream & Decurrent & Infundibuliform \\
\hline T5 & Cottony & Exuberant & Cream & Decurrent & $\begin{array}{l}\text { Flabelliform/ } \\
\text { Malformations }\end{array}$ & Cottony & Regular & Cream & Decurrent & Infundibuliform \\
\hline
\end{tabular}

Table 6

Proximal chemical analysis of the mushrooms from the WG and WP experiments.

\begin{tabular}{|c|c|c|c|c|c|c|c|c|}
\hline & \multicolumn{4}{|l|}{ WG } & \multicolumn{4}{|l|}{ WP } \\
\hline & $M(\%)$ & C (\%) & CP (\%) & EE (\%) & $\mathrm{M}(\%)$ & C (\%) & $\mathrm{CP}(\%)$ & EE (\%) \\
\hline $\mathrm{T} 1$ & $86.33 \pm 2^{a}$ & $8.09 \pm 0.2^{a}$ & $26.27 \pm 0.7^{a}$ & $6.58 \pm 0.1^{a}$ & $85.22 \pm 2^{a}$ & $7.37 \pm 0.2^{\mathrm{a}}$ & $16.03 \pm 0.4^{a}$ & $7.76 \pm 0.1^{a}$ \\
\hline $\mathrm{T} 2$ & $89.58 \pm 1^{b}$ & $7.58 \pm 0.1^{a}$ & $23.22 \pm 0.7^{b}$ & $6.02 \pm 0^{a}$ & $89.58 \pm 1^{b}$ & $7.64 \pm 0.2^{a}$ & $15.84 \pm 0.9^{a}$ & $7.88 \pm 0.5^{a}$ \\
\hline T3 & $89.14 \pm 2^{b}$ & $7.67 \pm 0^{a}$ & $22.73 \pm 0.6^{b}$ & $6.50 \pm 0.1^{a}$ & $87.85 \pm 2^{\mathrm{a}}$ & $8.17 \pm 0.1^{b}$ & $21.89 \pm 0.9^{b}$ & $8.18 \pm 0.1^{a}$ \\
\hline $\mathrm{T} 4$ & $89.83 \pm 1^{b}$ & $7.42 \pm 0.6^{a}$ & $21.91 \pm 0.5^{b}$ & $7.13 \pm 0.1^{a}$ & $89.83 \pm 1^{b}$ & $8.21 \pm 0.1^{b}$ & $24.86 \pm 0.6^{c}$ & $7.90 \pm 0.1^{a}$ \\
\hline $\mathrm{T} 5$ & $88.86 \pm 0.7^{b}$ & $8.25 \pm 0.3^{a}$ & $15.20 \pm 0^{c}$ & $6.83 \pm 0^{a}$ & $89.02 \pm 1^{b}$ & $8.29 \pm 0^{b}$ & $22.94 \pm 0.2^{b}$ & $8.36 \pm 0^{b}$ \\
\hline $\begin{array}{l}\text { T1: } \\
\text { Mea } \\
\text { Stan }\end{array}$ & $\begin{array}{l}\text { strate not supplen } \\
\text { ot labeled with th } \\
\text { d deviation }\end{array}$ & $\begin{array}{l}\text { d; } T 2: 0.95 \% \text { of } n \\
\text { er "a" are signific }\end{array}$ & $\begin{array}{l}\text { en; } \mathrm{T} 3: 1.14 \% \text { of ni } \\
\text { different from the }\end{array}$ & $\begin{array}{l}n ; \mathrm{T} 4: 1.32 \% \text { of } n \\
n \text { of the control I }\end{array}$ & $\begin{array}{l}\text { yen; T5: } 1.5 \% \text { of } \\
n \text { the Tukey Mul }\end{array}$ & $\begin{array}{l}\text { gen; M: Moisture; } \\
\text { Comparison Test }\end{array}$ & $\begin{array}{l}\text { sh; CP: Crude prot } \\
\text { a significance lev }\end{array}$ & $\begin{array}{l}\text { E: ethereal extra } \\
\leq 0.05) . \pm\end{array}$ \\
\hline
\end{tabular}

The moisture determined for the fruiting bodies in this study ranged from $85.22-89.83 \%$ in the two experiments and showed statisticallysignificant differences with respect to controls (T1) ( $\mathrm{p} \leq 0.05)$. The highest CP content $(26.27 \%)$ occurred in T1 of the mushrooms inoculated with WG without added nitrogen. We expected that in addition to improving BE and PR, supplementing the substrate with a source of $\mathrm{N}$ (urea) would increase CP content, but as the concentration of urea in the substrate increased in the WG treatments, the CP of the mushrooms decreased significantly. Although the concentration of CP in the mushrooms inoculated with WP achieved a value considered typical for this species, it was below the level of the mushrooms inoculated with WG. Treatment T4 (WP) had the highest protein content. On the other hand, the mushrooms in experiments WG and WP the fat content, ranged from 7.42-8.36\%. Regarding ash content, the sporomes obtained from WG and WP in the present study contained $7.3-8.3 \%$.

\section{Discussion}

The mushrooms that grow on plants of the genera Opuntia, Yucca, Agave, and Phytolacca, among others, are described as $P$. opuntiae, but because worldwide the genus Pleurotus includes several taxa and species, controversy exists due to the absence of valid sequencing data and/or phylogenetic reconstructions. This has generated significant ambiguities regarding the exact identity and distribution of $P$. opuntiae (Zervakis et al. 2019). The mushroom $P$. djamor has a cosmopolitan distribution that includes species identified as $P$. ostreatoroseus, $P$. parsonsiae, and $P$. salmoneostramineus. $P$. djamor is a pantropical species found in wild form in several countries in the America, including Mexico, though its distribution is probably much broader (Zervakis et al. 2019). Molecular studies have of $600-800$ pb have been reported for $P$. abalonus, P. cystidiosus, $P$. cystidiosus var. Formosensis, $P$. fuscoquamulosus, $P$. smithii, and $P$. australis (Zervakis et al. 2004), P. djamor, $P$. cornucopiae, P. cystidiosus, and P. pulmonaris (Imtiaj et al. 2011), but recently fragments of 700 pb were found for $P$. djamorand $P$. ostreatus (Doroteo et al. 2018). 
Mushrooms of the genus Pleurotus have the ability to grow on materials with low nitrogen concentrations. The results of our nitrogen analysis indicate that the bagasse of $A$. salmiana is a good candidate for use as an alternative substrate for cultivating edible mushrooms. Nitrogen is essential for protein synthesis, purines, pyridine, and chitin in mushrooms, but high levels can shrink yields (Chang and Miles 2004). Thus, it is extremely important to ensure that the substrates utilized to cultivate edible mushrooms contain an adequate nitrogen content that will allow correct growth. According to Heredia-Solís et al. (2014), the content of CP in A. salmiana and Agave weberi bagasse does not exceed 4\%. In this study the nitrogen content in the bagasse, pineapples, and the mixture (50:50) was measured at $0.77,1.84$, and $1.40 \%$, respectively; figures that concur with those reported for bagasse, which range from 0.1-1\% of $\mathrm{N}$ (Obodai et al. 2003; Koutrotsios et al. 2014).

During the cultivation of fungi, the type of inoculum WP represents a competitive advantage, against other microorganisms that could compete for the substrate and contaminate the culture. Due to its origin, the inoculum in pellet does not harbor spores of other fungi or microorganisms because it exerts greater control (Rosado et al. 2002; Abdullah et al. 2013). According to Khanna et al. (1992), the precociousness in Pleurotus spp. ranges from 24-30 days, though Kalmis and Sargin (2004) and Naraian et al. (2009) reported the appearance of primordia at 22 and 20 days, respectively. For $P$. opuntiae, the appearance of primordia occurred at 30 days (Barrales and Mata 2016). In the present study, the time of appearance of the primordia of $P$. djamor was lower and similar to observations by Salmones et al. (2005); that is, greater precociousness of $P$. djamor after 11 and 13 days on wheat chaff and coffee pulp, respectively. Supplementing substrates with nitrogenated sources improves the production of mushrooms of the genus Pleurotus spp. (Naim et al. 2020). But other observations have shown deficiencies in mycelial growth and yields when nitrogen sources such as ammonium chloride were applied to $P$. ostreatus and P. cystidiosus at concentrations above 0.09 and $0.05 \%$ (Hoa and Wang, 2015), and with ammonium sulfate and urea at concentrations of $1 \%$ and $1.5 \%$, respectively (Naraian et al. 2009).

The growth, development, quality, and quantitative aspects (biological efficiency, productivity) are closely-related to the type of nutrients present in the substrate, an equilibrium in the $\mathrm{C} / \mathrm{N}$ ratio, and other conditions of cultivation (Mukhopadhyay et al. 2002; Curvetto et al. 2002; Bellettini et al. 2019). In this study the absence of a second harvest could be due to the inoculum in pellet form (WP) since it did not contain the characteristic nutrients of wheat grain that provide energy for mycelial growth and development (Royse et al. 2004). Other possibilities include the nutritional exhaustion of the substrate during mushroom growth, and/or the accumulation of toxic substances that impeded fructification (Upadhyay et al. 2002). The $\mathrm{C} / \mathrm{N}$ ratio is a determining factor for mushroom production because excess nitrogen can affect the degradation of lignin, thus impeding the development of the mycelium and the formation of fruiting bodies. In the phase of development of the fruiting bodies, a low $\mathrm{C} / \mathrm{N}$ ratio is favorable. Bellettini et al. (2015) recommend an $\mathrm{C} / \mathrm{N}$ ratio of $28-30$ of carbon and $1 \%$ nitrogen for growing mushrooms. Heredia-Solís et al. (2014) reported the same BE with $P$. ostreatus using a substrate made of bagasse of $A$. salmiana and $40 \%$ of BE with $A$. weberi. In other results, a BE of $60.2 \%$ was obtained with Agave tequilana (Soto-Velazco 1989 ), and of $33.24 \%$ using a substrate of bagasse of Agave angustifolia mixed with 30\% nogal shavings and 5\% wheat bran (Heredia-Solís et al. 2016). Deformations of the fruiting bodies - especially elongated stipes and reduced coloration- have been reported due to the effects of cultivating conditions (high luminosity, temperature during fructification, $\mathrm{CO} 2$ levels) (Urben 2004). However, considering that the environmental conditions in the present study were the same for all levels of nitrogen in the substrate, we deduced that higher $\mathrm{N}$ concentrations inhibited the growth of the fruiting bodies (Kanhar et al. 2007; Monterroso et al. 2009; Hoa and Wang 2015), and induced deformations in the mushrooms. High N content also produced slow growth of the stems of the fruiting bodies and delays their formation. It is possible, therefore, that the malformations found in this study are related to an imbalance of the $\mathrm{C} / \mathrm{N}$ ratio.

The nutritional quality and composition of the fruiting bodies depends on both the cultivation conditions (temperature, moisture, $\mathrm{pH}$, etc.) and the substrate, since this is the source of the nutrients and lignocellulosic material that supports growth, development, and fructification. The use of a waste lignocellulosic material as substrate is key to maximizing yields and enhancing product disposition (Chang and Miles 2004; Sardar et al. 2017). For this reason, we opted to cultivate P. djamor on the same source from which it was isolated (i.e., A. salmiana bagasse). One of the most important parameters for this type of food is the amount of protein content, since it is well-known that species of Pleurotus spp. grow on substrates with low nitrogen content yet the fruiting bodies they produce have higher concentrations of N. Protein content, however, is influenced by factors that include the nature and nutritional components of the substrate, the strain, the stage of development, and the timing of post-harvest analysis (Cowling and Merrill 1966; Sardar et al. 2017). The genus Pleurotus sp. is characterized by low fat content, high protein content, and a low concentration of lipids in the fruiting bodies (Bellettini et al. 2019).

In this study the CP content of the fruiting bodies in our WP and WG treatments was found to be within the ranges established for the genus Pleurotus, that is, $17-25 \%$ (Lelley 2017), with 20.3\% of CP for P. ostreatus (Del Toro et al. 2018), and 20.7-28\% for P. djamor (Salmones 2017). In studies of Pleurotus spp. cultivated in supplemented bagasse, Ortega et al. (1992) described an increase of nitrogen in the mushrooms that was related to the amount of $\mathrm{N}$ present in the initial substrate and to the inoculum. Sturion and Oetterer (1995) suggested that mushrooms might be fixing this element. Wheat seeds can provide nutrients to the inoculum that enrich the substrate and define the development of the mycelium in early stages; however, because the inoculum with WP did not contain nutrients from wheat, it may have impeded optimal growth. Therefore, it is probable that the type of substrate and inoculum influence the nutritional composition of the fruiting bodies (Bellettini et al. 
2019). Also the percentage of moisture depends on the strain, substrate, and growing environment (temperature, relative humidity) (Guillamón et al. 2010). The moisture percentages for this species indicate 85-90.9\% (Sardar et al. 2017).

The results obtained from the chemical composition analysis in this study suggest that $P$. djamoris a promising food for several types of diet due to its nutritional quality (Salmones 2017). Up to now, this mushroom has not been cultivated on $A$. salmiana bagasse, but its high adaptability to cultivation conditions could well make it attractive in international markets as an exotic mushroom that can be cultivated on maguey bagasse.

The suitability of a substrate for cultivating mushrooms depends on its chemical composition, availability, and cost. In this regard, residual $A$. salmiana bagasse from pulque, inulin, and agave honey production is a promising option that can compete on a small scale with other substrates, since its generation is growing daily, with reports of the generation of 0.5 tons of bagasse from inulin production, and 0.16 tons from producing just 0.4 tons of agave honey (Hoz-Zavala et al. 2017). In addition, its availability, though not specific, contains the elements necessary for the developmental and reproductive functions of edible mushrooms (Salmones et al. 2005; Heredia-Solís et al. 2017; Gallardo 2018). Moreover, in comparison to similar substrates, when supplemented with urea it reaches a BE greater than that of bagasse of $A$. tequilana, A. augustifolia, and $A$. weberi. In general, then, exploiting $A$. salmiana bagasse represents a sustainable option in ecological, social, and commercial terms (Heredia-Solís et al. 2014; Heredia-Solís et al. 2017).

This is the first report to address the isolation of $P$. djamor of Agave salmiana and grown on bagasse of Agave salmiana as an atypical substrate. During cultivation on $A$. salmiana bagasse, the growth of the fruiting bodies depended on the type of inoculum and the concentration of urea. Supplementing the substrate with urea (1.32\%) to provide nitrogen improved both BE and PR by as much as $70 \%$ and 1.17, respectively, in the cultivation of $P$. djamor. At higher concentrations (1.5\%), however, this inhibited the growth of the fruiting bodies and produced malformations. A. salmiana bagasse is a suitable alternative substrate due to its chemical composition and high availability because it permits the growth of the mushroom without altering the optimal nutritional composition of this genus, thus providing economic and environmental advantages. Results represent an invitation for further study and commercialization.

\section{Declarations}

\section{Funding}

The authors thank CONACYT for Fellowship No. 732368 granted for the Doctor's Degree studies of Brianda Susana Velázquez De Lucio.

\section{Competing interests}

The authors declare that they have no competing interests

\section{Availability of data and material}

\section{Code availability}

Not applicable

\section{Authors' contributions}

Brianda Susana Velázquez de Lucio: Investigation, formal analysis, writing - original draft.

Edna María Hernández-Dominguez: Resources, conceptualization, supervision, writing - review y editing.

Xóchitl Tovar-Jiménez: Methodology: writing - review and editing

Gerardo Díaz-Godínez: Methodology, writing - review and editing.

Alejandro Téllez Jurado: Conceptualization, methodology, writing - review and editing.

Jorge Álvarez Cervantes: Conceptualization, term, methodology, writing - review and editing, visualization.

\section{Ethics approval}

Not applicable

\section{Consent to participate}


Not applicable

\section{Consent for publication}

Not applicable

\section{Data availability}

The datasets generated during and/or analysed during the current study are available in the GenBank repository, under access number MW581271, the phylogenetic tree was deposited in TreeBASE (Reviewer access URL: http://purl.org/phylo/treebase/phylows/study/TB2:S28312?x-access-code=288be19013aeff456bd2b892c2905a0e\&format=html); and this are available from the corresponding author on reasonable request.

\section{References}

Abdullah N, Ismail R, Johari NMK, Annuar MSM (2013) Production of liquid spawn of an edible grey oyster mushroom, Pleurotus pulmonarius (Fr.) Quél by submerged fermentation and sporophore yield on rubber wood sawdust. Sci Hortic. 161: 6569. https://doi.org/10.1016/j.scienta.2013.06.026

Al-Hatmi AM, Meis JF, de Hoog GS (2016) Fusarium: molecular diversity and intrinsic drug resistance. PLoS pathogens, 12: e1005464. https://doi.org/10.1371/journal.ppat.1005464

Altschul SF, Gish W, Miller W, Myers EW, Lipman DJ (1990) Basic local alignment search tool. J Mol Biol. 215:403410. https://doi.org/10.1016/s0022-2836(05)80360-2

AOAC (1990) Official methods of analysis of the AOAC, 15th ed. Association of official analytical chemists. Arlington, VA, USA.

Arango CS, Nieto IJ (2013) Cultivo biotecnológico de macrohongos comestibles: una alternativa en la obtención de nutracéuticos. Rev Iberoam Micol. 30:1-8 https://doi.org/10.1016/j.riam.2012.03.011

Barba BM, Assumpção FF, Aparecida MH, Lopés TG, Ávila S, Silveira HP, Maccari JA, Hoffmann RR (2016) Factors affecting mushroom Pleurotus $\quad$ spp. Saudi J Biol Sci. 1: 1-14. https://doi.org/10.1016/j.sjbs.2016.12.005

Barrales M, Mata G (2016) Selección de cepas nativas del hongo de maguey (Pleurotus opuntiae) y evaluación de su producción en sustratos fermentados. Interciencia. 41:346-352. http://www.redalyc.org/articulo.oa?id=33945552010. Accessed 20 July 2020.

Bellettini MB, Fiorda FA, Bellettini S (2015) Aspectos gerais do cultivo de cogumelo Pleurotus ostreatus e djamorpela te'cnica Jun Cao. Apprehendere, Guarapuava.

Bellettini MB, Fiorda FA, Maieves HA, Teixeira GL, Ávila S, Hornung PS et al (2019) Factors affecting mushroom Pleurotus spp. Saudi J Biol Sci. 26:633-646. https://doi.org/10.1016/j.sjbs.2016.12.005

Bernabé-González T, Cayetano-Catarino M., Adán-Díaz A, Torres-Pastrana MA (2004) Cultivo de Pleurotus pulmonarius sobre diversos subproductos agrícolas de Guerrero, México. Rev Mex Mic. 18: 77-80. https://doi.org/10.33885/sf.2004.3.917

Chang ST, Miles PG (2004) Cultivation, Nutritional Value, Medicinal Effect and Environmental Impact of Mushrooms. CRC Press. Bora Raton, London.

Chevenet F, Brun C, Bañuls AL, Jacq B, Christen R (2006) TreeDyn: towards dynamic graphics and annotations for analyses of trees. BMC bioinformatics 7:439 https://doi.org/10.1186/1471-2105-7-439

Cowling EB, Merrill W (1966) Nitrogen in wood and its role in wood deterioration. Can J Bot. 44:1539-1554. https://doi.org/10.1139/b66-167

Crespo GMR, González EDR, Rodríguez MR, Ruiz CJA, Durán PN (2018) Caracterización química y física del bagazo de agave tequilero compostado con biosólidos de vinaza como componente de sustratos para cultivos en contenedor. Rev Int Contam Ambient. 34:373-382. https://doi.org/10.20937/rica.2018.34.03.01

Curvetto NR, Figlas D, Devalis R, Delmastro S (2002) Growth and productivity of different Pleurotus ostreatus strains on sunflower seed hulls supplemented with N-NH4 + and/or Mn (II). Bioresour Technol. 84:171-176. https://doi.org/10.1016/S0960-8524(02)00013-5 
Del Toro GV, Ramírez-Ortiz ME, Flores-Ramírez G, Costa-Manzano MR, Robles-Martínez F, Garín-Aguilar ME, Leal-Lara H (2018) Effect of Yucca schiedigera bagasse as substrate for oyster mushroom on cultivation parameters and fruit body quality. Rev Mex Ing Quím. 846 https://doi.org/10.24275/uam/izt/dcbi/revmexingquim/2018v17n3/Valencia

Dereeper A, Audic S, Claverie JM, Blanc G (2010) BLAST-EXPLORER helps you building datasets for phylogenetic analysis. BMC Evol Biol. 10:16. https://doi.org/10.1186/1471-2148-10-8

Dereeper A, Guignon V, Blanc G, Audic S, Buffet S, Chevenet F, et al (2008) Phylogeny. fr: robust phylogenetic analysis for the nonspecialist. Nucleic Acids Res. 36:W465-W469. https://doi.org/10.1093/nar/gkn180

Díaz AS, Rentería LF, Cortez JA, Palacios ES (2014) PCR: reacción en cadena de la polimerasa. In: Cornejo RA, Serrato DA, Rendón A, Rocha MMG (Ed) Herramientas moleculares aplicadas en ecología: aspectos teóricos y prácticos, SEMARNAT, México.

Doroteo LA, Segura PBZ, Arce RV, Fernández JY, Aguilar MEG, Mendoza PCG, del Toro GV (2018) Utilización de marcadores ITS e ISSR para la caracterización molecular de cepas híbridas de Pleurotus djamor. Rev Iberoam Micol. 35:49-55 https://doi.org/10.1016/j.riam.2017.06.003

Fernández F (2004) Guía práctica de producción de Setas (Pleurotus spp.) Fungitec Asesorías. Guadalajara, Jalisco. México.

Gallardo J (2018) Industria del tequila y generación de residuos. Ciencia y Desarrollo CONACYT. https://www.cyd.conacyt.gob.mx/? p=articulo\&id=287 Accesed 08 September 2020.

Gouleke CG (1977) Biological processing: Composting and hydrolisis. In: Wilson DG (ed) Handbook of solid waste management. Van Norstrand Reinhold, Nueva York, pp. 197-225

Granados SD (1993) Los Agaves en México. México: Universidad Autónoma de Chapingo. México.

Gregori A, Svagelj M, Pohleven J (2007) Cultivation Techniques and Medicinal Properties of Pleurotus spp. Food Technol Biotechnol. 45: 238-249.

Guillamón E, García-Lafuente A, Lozano M, Rostagno MA, Villares A, Martínez JA (2010) Edible mushrooms: role in the prevention of cardiovascular diseases. Fitoterapia 81:715-723. https://doi.org/10.1016/j.fitote.2010.06.005

Heredia-Solís A, Bañuelos-Valenzuela R, Esparza-lbarra E (2017) Producción de Pleurotus ostreatus sobre sustratos de Agave salmiana y Agave weberi. Biotecnología y Sustentabilidad 2:31-36.

Heredia-Solís A, Esparza-lbarra E, Romero-Bautista L, Cabral-Arellano F, Bañuelos-Valenzuela R (2014) Bagazos de Agave salmiana y Agave weberi utilizados como sustrato para producir Pleurotus ostreatus. RelbCi 1:103-110.

Hoa HT, Wang CL (2015) The effects of temperature and nutritional conditions on mycelium growth of two oyster mushrooms (Pleurotus ostreatus and Pleurotus cystidiosus). Mycrobiology 43:14-23. https://doi.org/10.5941/myco.2015.43.1.14

Hoz-Zavala M, Esther E, Nava-Diguero P (2017) Situación del Agave y sus residuos en Tamaulipas. Revista de energías Renovables. 1:19-31. Huanca-Mamani W, Martínez RS, Sepúlveda-Chavera G (2014) A fast and efficient method for total DNA extraction from soil filamentous fungi. Idesia 32:75-78.

Huelsenbeck JP, Ronquist F (2001) MRBAYES: Bayesian inference of phylogenetic trees. Bioinformatics 17:754755. https://doi.org/10.1093/bioinformatics/17.8.754

Huerta G, Martínez-Carrera D, Sánchez JE, Leal-Lara H, Vilgalys R (2010) Genetic relationships between Mexican species of Pleurotus analyzing the ITS-region from rDNA. Micol Aplicada Int. 22:15-25. http://www.redalyc.org/articulo.oa?id=68512102002 Accessed 09 January 2021.

Imtiaj A, Lee TS, Ohga S (2011) Sequence variation of Pleurotus species collected from Eastern Asia. Micol Aplicada Int. 23:110. http://www.redalyc.org/articulo.oa?id=68516112001 Accessed 15 May 2020.

Johney J, Sri SR, Ragunathan R (2018) Extraction of Chitin and Chitosan from Wild Type Pleurotus Spp and its Potential ApplicationInnovative Approach. J Pure Appl Microbiol 12:1631-1640. https://dx.doi.org/10.22207/JPAM.12.3.70

Kalmis E, Sargin S (2004) Cultivation of two Pleurotus species on wheat straw substrates containing olive mill waste water. Int Biodeterior Biodegradation. 53:43-47. https://doi.org/10.1016/j.ibiod.2003.08.002 
Kanhar QD, Jiskani MM, Pathan MA, Nizamani ZA (2007) Effect of urea on growth and yield of oyster mushroom, Pleurotus ostreatus (JACQ.EX.FR.) Kummer. Pakistan J Phytopathol 19:214-223.

Khanna PK, Bhandari R, Soni GL, Garcha HS (1992) Evaluation of Pleurotus spp. for growth, nutritive value and antifungal activity. Indian J Microbial. 32:197-200.

Koutrotsios G, Mountzouris KC, Chatzipavlidis I, Zervakis GI (2014) Bioconversion of lignocellulosic residues by Agrocybe cylindracea and Pleurotus ostreatus mushroom fungi - Assessment of their effect on the final product and spent substrate properties. Food Chem. 161: 127-135. https://doi.org/10.1016/j.foodchem.2014.03.121

Krishnapriya PJ, Geetha D (2017) Proximate constitution and antiproliferative activity of Pleurotus opuntiae (Durieu and Lev.) Sacc. against colon cancer. Int J Curr Microbiol Appl Sci. 6: 1406e1414. https://doi.org/10.20546/IJCMAS.2017.605.153

Lelley J (2017) Aspectos nutritivos de las setas Pleurotus spp. In: Sánchez JE, Royse DJ (ed) La biología, el cultivo y las propiedades nutricionales y medicinales de las setas Pleurotus spp. ECOSUR, México pp 117-196.

López-Rodríguez C, Hernández-Corredor R, Suárez-Franco C, Borrero M (2008) Evaluación del crecimiento y producción de Pleurotus ostreatus sobre diferentes residuos agroindustriales del departamento de Cundinamarca. Univ Sci. 13:128-137. http://www.redalyc.org/articulo.oa? id=49913204 Accessed 11 October 2020 .

Monterroso FOG (2009) Efecto de la suplementación de la caña de maíz (Zea mays L.) con nitrato de amonio, nitrato de potasio y urea en el cultivo del hongo Pleurotus ostreatus (Cepa ECS-152). Tesis Doctoral. Universidad de San Carlos de Guatemala. http://www.repositorio.usac.edu.gt/9488/ Accessed 20 November 2020.

Mukhopadhyay R, Chatterjee BP, Guha AK (2002) Biochemical changes during fermentation of edible mushroom Pleurotus sajorcaju in whey. Process Biochem. 38:723-725. https://doi.org/10.1016/S0032-9592(02)00192-9

Naim L, Alsanad MA, El Sebaaly Z, Shaban N, Abou FS, Sassine YN (2020) Variation of Pleurotus ostreatus (Jacq. Ex Fr.) P. Kumm (1871) performance subjected to different doses and timings of nano-urea. Saudi J Biol Sci. 27:1573-

1579 https://doi.org/10.1016/j.sjbs.2020.03.019

Naraian R, Sahu RK, Kumar S, Garg SK, Singh CS, Kanaujia RS (2009) Influence of different nitrogen rich supplements during cultivation of Pleurotus florida on corn cob substrate. Environmentalist 29:1-7. https://doi.org/10.1007/s10669-008-9174-4

Nylander JAA (2004) MrModeltest Version 2. Uppsala University, Uppsala http://www.abc.se/ nylander/. program distributed by the author

Obodai M, Cleland-Okine J, Vowotor KA (2003) Comparative study on the growth and yield of Pleurotus ostreatus mushroom on different lignocellulosic by-products. J Ind Microbiol Biotechnol 30:146-149. https://doi.org/10.1007/s10295-002-0021-1

Ortega GM, Martínez EO, Betancourt D, González AE, Otero MA (1992) Bioconversion of sugar cane crop residues with white-rot fungi Pleurotus sp. World J Microbiol Biotechnol 8:402-405. https://doi.org/10.1007/BF01198754

Portilla-Segura A, Romero-Arenas O, Valencia de Ita MA, Hernández EMA, Lanteta CG, Rivera-Tapia JA (2019) Determinación de los parámetros de productividad de cepas de Pleurotus ostreatus y $P$. opuntiae cultivadas en paja de trigo y pencas de maguey combinadas con sustratos agrícolas. Scientia Funforum. 49:e1216 https://doi.org/10.33885/sf.2019.49.1216

Rambaut, A. (2018) FigTree v1. 4. 4. Institute of Evolutionary Biology, University of Edinburgh, Edinburgh. http://tree.bio.ed.ac.uk/software/figtree/

Rosado FR, Kemmelmeier C, Gomes Da Costa SM (2002) Alternative method of inoculum and spawn production for the cultivation of the edible Brazilian mushroom Pleurotus ostreatoroseus Sing. J Basic Microbiol 42:37-44. https://doi.org/10.1002/1521-

4028(200203)42:1\%3C37::aid-jobm37\%3E3.0.co;2-s

Royse DJ, Baars J. Tan Q (2017) Current Overview of Mushroom Production in the World. In: Diego CZ, and Pardo-Giménez A (ed). Edible and Medicinal Mushrooms: Technology and Applications. Wiley-Blackwell. https://doi.org/10.1002/9781119149446.ch2

Royse DJ, Rhodes TW, Ohga S, Sanchez JE (2004) Yield, mushroom size and time to production of Pleurotus cornucopiae (oyster mushroom) grown on switch grass substrate spawned and supplemented at various rates. Bioresour Technol. 91:85-91. https://doi.org/10.1016/s09608524(03)00151-2 
Royse DJ, Sánchez VJE (2001) La importancia del cultivo de Pleurotus spp. Estadísticas mundiales de producción, con énfasis en Hispanoamérica. In: Sánchez JE, Royse DJ (ed). La biología y el cultivo de Pleurotus spp. ECOSUR, México pp. $19-26$.

Salmones D (2017) Pleurotus djamor, un hongo con potencial aplicación biotecnológica para el neotrópico. Rev Mex Micol. 46:7385. https://doi.org/10.33885/sf.2017.46.1177

Salmones D, Mata G, Waliszewski K (2005) Comparative culturing of Pleurotus spp. on coffee pulp and wheat straw: biomass production and substrate degradation. Bioresour Technol. 96: 537-544. https://doi.org/10.1016/j.biortech.2004.06.019

Sardar H, Ali MA, Anjum MA, Nawaz F, Hussain S, Naz S, Karimi SM (2017) Agro-industrial residues influence mineral elements accumulation and nutritional composition of king oyster mushroom (Pleurotus eryngii). Sci Hortic. 225:327-334.

Soto-Velazco C, Guzmán-Dávalos L, Rodríguez O (1989) Cultivo del hongo comestible Pleurotus ostreatus sobre bagazo de maguey tequilero fermentado y mezclado con paja de trigo. Rev Mex Micol. 5:97-101. https://doi.org/10.33885/sf.1989.3.743

Sturion GL, Oetterer M (1995) Utilizac, a o da folha da bananeira como substrato para cultivo de cogumelos comestı́veis (Pleurotus spp.). Cie^nc. Tecnol. Alimen. 15, 194-200 (in Portuguese) https://doi.org/10.11606/D.11.2019.tde-20191218-132526

Thompson JD, Higgins DG, Gibson TJ (1994) CLUSTAL W: improving the sensitivity of progressive multiple sequence alignment through sequence weighting, position-specific gap penalties and weight matrix choice. Nucleic Acids Res. 22:4673-

4680. https://doi.org/10.1093/nar/22.22.4673

Upadhyay RC, Verma RN, Singh SK, Yadav MC (2002) Effect of organic nitrogen supplementation Pleurotus sp. The 4th ICMBP. 112 https://www.researchgate.net/profile/Dr-Mahesh-

Yadav/publication/288934259_Effect_of_organic_nitrogen_supplementation_in_Pleurotus_species/links/5b1fc576458515270fc55e45/Effectof-organic-nitrogen-supplementation-in-Pleurotus-species.pdf Accessed 20 May 2020.

Urben AF (2004) Produção de cogumelos por meio de tecnología chinesa modificada. Brasília: Embrapa Recursos Genéticos e Desenvolvimento.

Zervakis GI, Moncalvo JM, Vilgalys R (2004) Molecular phylogeny, biogeography and speciation of the mushroom species Pleurotus cystidiosus and allied taxa. Microbiology. 150:715-726. https://doi.org/10.1099/mic.0.26673-0

Zervakis GI, Venturella G, Fryssouli V, Inglese P, Polemis E, Gargano ML (2019) Pleurotus opuntiae revisited-An insight to the phylogeny of dimitic Pleurotus species with emphasis on the P. djamor complex. Fungal Biol. 123:188-199. https://doi.org/10.1016/j.funbio.2018.12.005

\section{Figures}




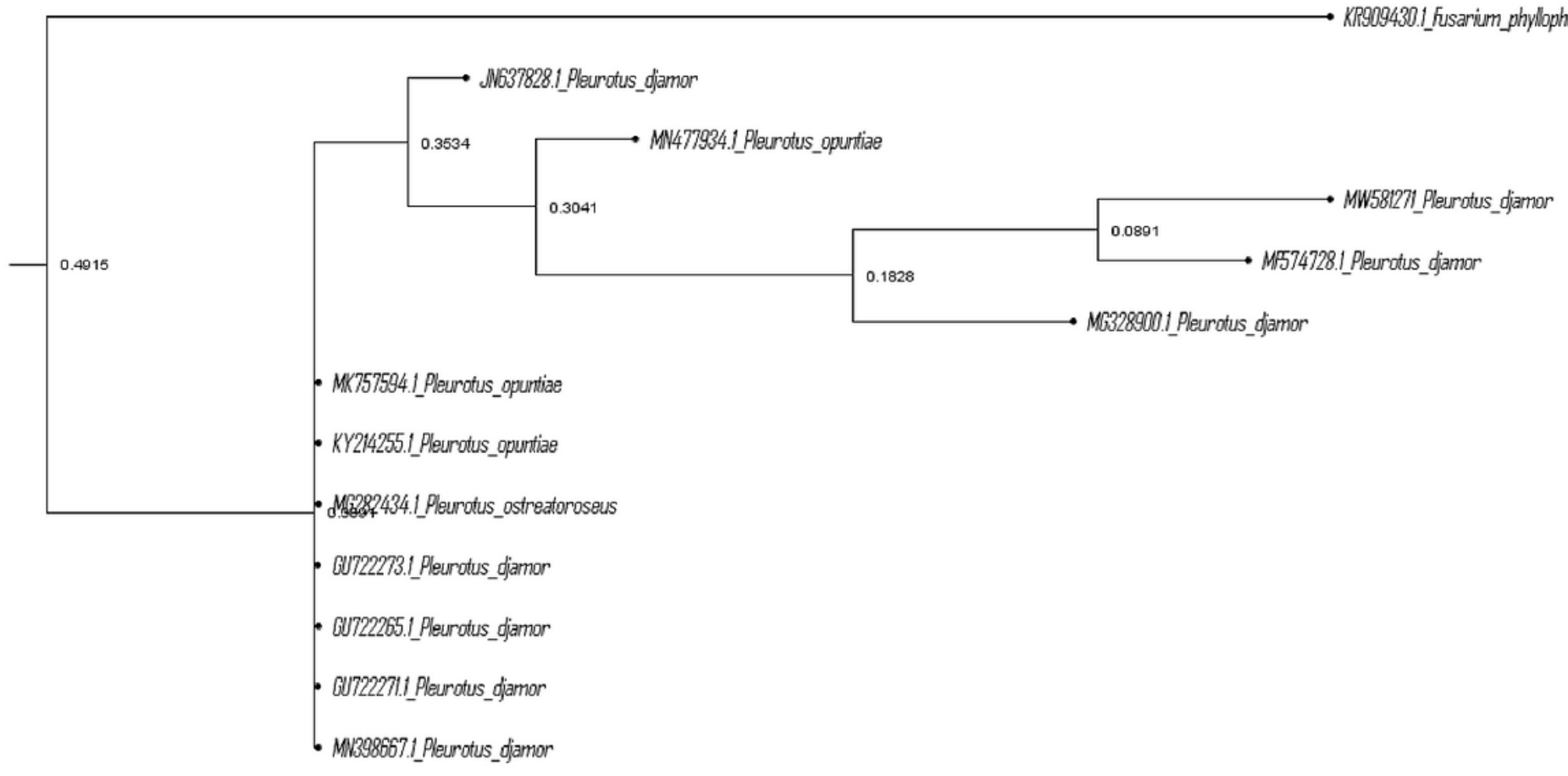

0.05

Figure 1

Phylogenetic tree generated from the sequences of the ITS region of strains of Pleurotus.

T1

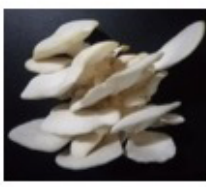

WP

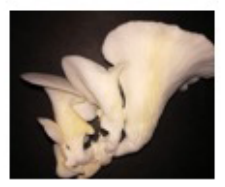

T2
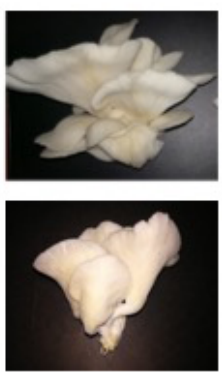

$\mathrm{T} 3$
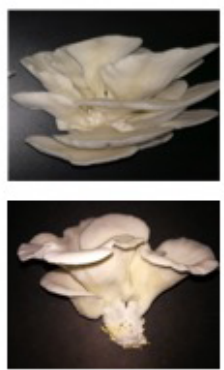

T4
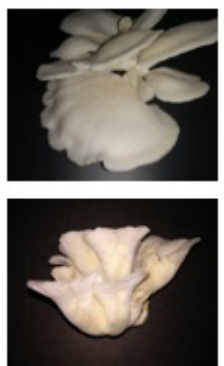

T5

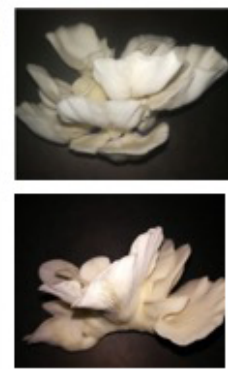

Figure 2

Fruiting bodies from the different treatments of the experiments with WG and WP. The bodies are of beige color, with regular growth, cottony texture, and decurrent laminae. 
A)

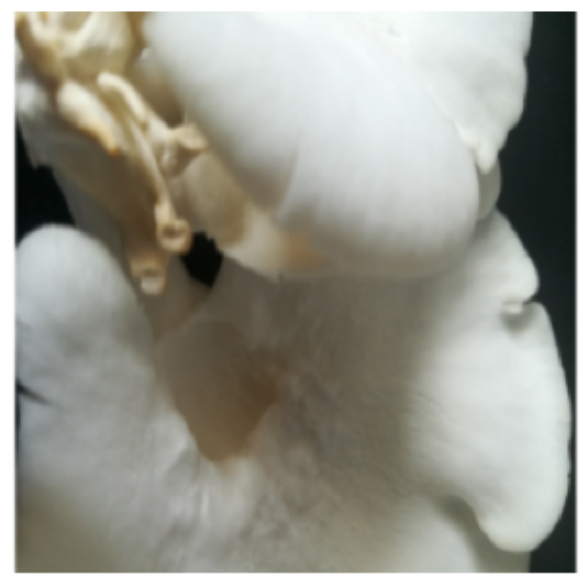

B)

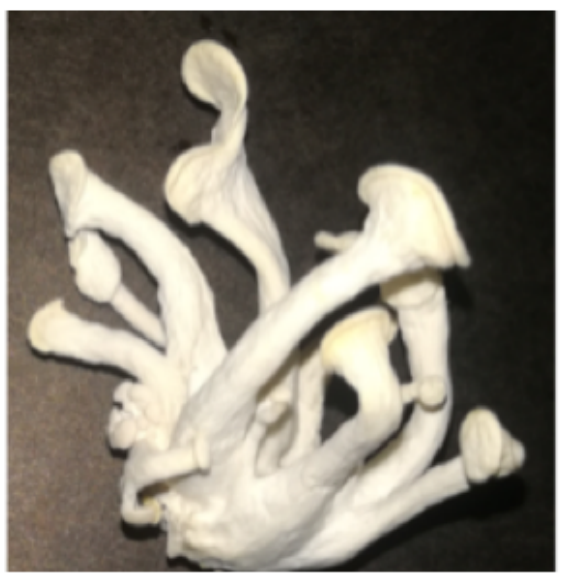

C)

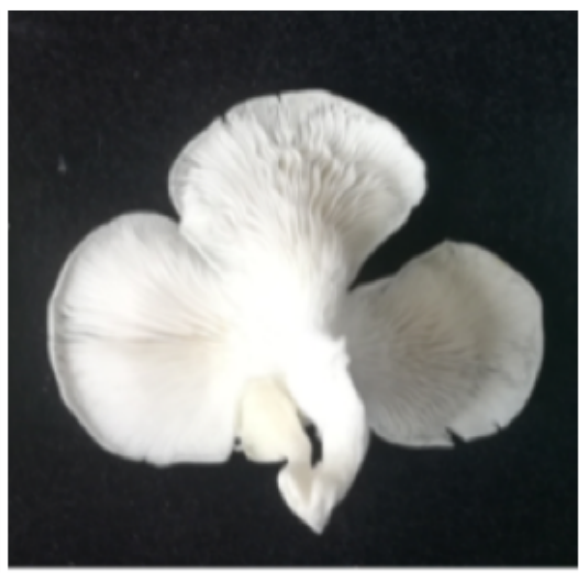

\section{Figure 3}

Malformations in the caps of Pleurotus djamor after adding $1.32 \%$ of $N$ in the WG experiment: a) perforation in the center of the caps; $b$ ) inhibition of the growth of the fruiting body; c) division of the carpophore.

\section{Supplementary Files}

This is a list of supplementary files associated with this preprint. Click to download.

- abstract.tif 